Thor Ola Engen

https://doi.org/10.26881/pwe.2018.42.04

ORCID: 0000-0001-8446-4440

Inland Norway University of Applied Sciences

thor.engen@inn.no

\title{
How metacognition and (reading) strategies develop according to Vygotsky
}

\begin{abstract}
Summary
The paper addresses the concepts of metacognition and (reading) strategies, the origin of which is usually traced back to the 1970s. However, the paper argues that conscious awareness, which Vygotsky introduced as early as the 1930s, is another term for metacognition. Further, according to Vygotsky, “... conscious awareness enters through the gate opened up by scientific concept" (Vygotsky 1987: 191, italics added), meaning that metacognitive skills develop in instruction, as a function of student's work with academic concepts. This hypothesis, however, seems to be ignored by contemporary, mainstream researchers. For example, an influential study like PIRLS, contradictory to Vygotsky's hypothesis, assumes that students already at the end of the elementary stage apply metacognitive skills - included reading strategies - in order to construct meaning in reading.
\end{abstract}

Keywords: metacognition, reading strategies, learning strategies, scientific concepts, Vygotsky

\section{Metacognition and metacognitive skills}

Based on a review of international research Roe (2014: 86) concludes that one major characteristic that competent and independent readers have in common is that they can monitor or supervise their own reading, by continuously controlling their own comprehension and effort. Thus, they have established the ability to think about their own thinking, which in the course of the 1970s was conceptualized as metacognition or metacognitive reflection (Flavell, Miller, \& Miller 2002 [1987]; Fox \& Risconscente 2008; Pressley 2000). Also the learning strategies and reading strategies concepts, which were introduced during the same period of time (Afflerback, Pearson, \& Paris 2008; Kulbrandstad 2018) are usually conceived of as the capability of experienced readers to control their reading efforts. The strategy concept also covers the ability to adapt one's approaches, if they do not result in acceptable comprehension, which is often the case when readers are exposed to texts experienced as demanding (Kulbrandstad 2018). Although there has been some lack of consistency in the use of the strategy concept as compared to the skills concept, many authors today agree that strategies are regulated by the reader's underlying metacognitive abilities (Afflerback et al. 2008). Partly on this background, but also based on a comprehensive research review, Rydland (2007) concludes that the mastery of reading strategies seems to be reserved exactly for the category of students who reading researchers refer to as good and independent readers. 
However, Haugen (2014: 153) - with a reference to Bernstein - suggests that readers, in order to develop learning (and reading) strategies, also need to be familiar with the specialized linguistic repertoire of different academic disciplines. She is supported by Klette (2007), who claims that students are exposed to the kind of texts they meet on the lower secondary stage in school, and they really need what Popkevitz (1998: 64) has labelled "technologies of the self"; an alternative term for metacognitive skills.

I have selected the research results summarized above in order to clarify certain central variables concerning the concept of metacognition and how it is developed. The observation that students' lack of metacognitive skills leads to failure in school when texts are experienced as demanding is quite common. However, it is not primarily students' subjective experiences with texts that influence their probability to succeed. Most fundamentally it is their familiarity with the specialized linguistic repertoire of different academic disciplines. Thus, the need for metacognitive skills will not become evident in school before students are introduced to academic texts, which usually takes place when students reach the lower secondary level.

At the introductory stage, both texts and instruction are designed for reading comprehension - word comprehension - to occur spontaneously, so that students are enabled to concentrate all their attention and efforts on what is considered the main task at this level, to establish fluent decoding skills. If comprehension occurs spontaneously, however, students are hardly in need of any metacognitively controlled strategies. By becoming fluent readers, students instead are being prepared to handle the academic texts of the middle stage, as fluent reading skills by reading researchers are considered the most fundamental condition for later academic success (e.g. Kulbrandstad 2018).

Fluent reading skills are therefore probably also a fundamental condition for student's capability to develop metacognitive skills. This is not necessarily a common assumption, however, as I will return to later, but it was, at least indirectly, Vygotsky's position, who is the main character in this article. His main hypothesis was that: “... conscious awareness enters through the gate opened up by scientific concept" (Vygotsky 1987: 191). Conscious awareness he defined as "... an act of consciousness whose object is the activity of consciousness itself(Vygotsky 1987: 190). Further he implied that the control required for conscious awareness is self-regulation, while the intentionality implied in his concept of self-regulation requires conscious awareness. As metacognition is often is defined as awareness and understanding of one's own thought processes (Fox \& Risconscente 2008), it is anticipated by the concept conscious awareness.

It should be added, however, that Vygotsky considered cognitive development as more important for the establishment of metacognitive skills, than students' reading skills us such, and that he also focused more on general instruction, than on reading instruction. To Vygotsky, then, students' reading skills were important primarily through their influence on students' readiness to take part in instruction in general, which at least at the secondary level is quite decisive.

Further, when Vygotsky's hypothesis also supports the assumption that students' familiarity with the specialized linguistic repertoire of different academic disciplines is de- 
cisive for the development of advanced metacognitive skills, so that metacognition and strategic thinking will not develop until the students reach the middle stage, it should also be emphasized that Vygotsky's main emphasis was on students' ability to think and reflect in academic categories, and not on linguistic competence as such. At the same time as this position reflects Vygotsky's focus on instruction in general, it also represents an independent aspect of his hypothesis. In my opinion, there are therefore several reasons to investigate the development of metacognition in relation to reading in the light of Vygotsky's hypothesis more thoroughly, which is my major ambition in the present article.

My most important motive for making Vygotsky's hypothesis and its educational implications a subject for explicit discussion, however, is the somewhat surprising observation that his perspectives seem to be quite unknown to - or at least are ignored by - many even influential Western reading researchers. For example, in the (Norwegian version of) the 2017 report from The Progress in International Reading Literacy Study (PIRLS), which (in 2016) was conducted, with reading comprehension as its main focus, in more than 50 participating countries (cf. for example Afflerback et al., 2008), Vygotsky's perspectives are not discussed at all. And as the study has been conducted every fifth year since the late 1990s, it has probably been quite influential, not only in the research community, but also among teachers, school leaders and school authorities.

There are several reasons to discuss how the study may have affected the general discourse on metacognition and (reading) strategies, especially as the concept of metacognition is more or less taken for granted in the PIRLS report. Admittedly, the researcher, in passing, points out that readers before, during and after reading apply a repertoire of linguistic, cognitive and metacognitive skills to construct meaning (Gabrielsen \& Strand, 2017 , p. 23). They also refer to dialogues where the students are invited to control and regulate their own comprehension, reading and learning, as well as goal achievement and the relationship between effort and outcome, as metacognitive reflections (Berge, Helgevold, \& Schulz-Heidorf, 2017, p. 168). These and other similar formulations indicate that what is taken for granted in the report is a conception of metacognition which corresponds quite closely to the concept as understood both by Vygotsky and in contemporary literature (e.g. Pressley 2000).

The same seems to be the case as far as reading strategies are concerned, as these by the PIRLS-researchers and with a reference to Afflerback et al. (2008: 368), are explicitly defined as: “ “.. deliberate, goal-directed attempts to control and modify the reader's efforts to decode text, understand words, and construct meanings of texts" (cf. Berge et al. 2017: 167). As is emphasized in the report that it is the relationship to metacognition that differentiates reading strategies from any other reading activity (Berge et al. 2017: 168), the formulations that strategies are deliberate, goal-directed attempts to control and modify $[\ldots]$ reader's efforts to $[. .$.$] construct meanings of texts" indeed indicate a conception cor-$ responding to Vygotsky's.

What is somewhat confusing, however, is that the definition of strategies also suggests that “... reader's efforts [should be used] to decode text and understand words. Fluent 
decoding skills are normally established at the introductory stage, because instruction is arranged for reading comprehension to occur spontaneously. Thus, it is improbable that students at this level would need to make use of metacognitive skills. But if they do, such skills are hardly available to the students, if they enter through the gate opened up by scientific concept. My confusion is also awakened, by the description of the use of strategies in relation to word comprehension, as strategies on a surface level (Berge et al. 2017: 168). If strategies are "... deliberate, goal-directed attempts to [...] understand words... ", at the same time as they are also differentiated from other reading activities by their relationship to metacognition, they can hardly be functioning on a surface level.

Of course, some students, e.g. with minority language backgrounds, may need some support as far as text decoding and word comprehension are concerned, even at the middle stage. But as the students in question often have problems with their reading speed as well as with their ability to comprehend more comprehensive narratives" (Kulbrandstad 2003), and fluent decoding skills are a prerequisite for the comprehension of more academically demanding texts, it is highly improbable that such students will have access to metacognitive strategies for text decoding and word comprehension. This is especially improbable, if Vygotsky's hypothesis is valid, meaning that they will need to develop metacognition, while their attention is still preoccupied with the establishment of fluent reading skills.

Finally, it is also somewhat confusing in the light of Vygotsky's hypothesis that the PIRLS study put relatively great emphasis on the investigation of students' metacognitive skills, including their reading strategies (cf. Gabrielsen \& Strand 2017: 23), as long as its' target group is $4^{\text {th }}$ grade students. Although the data collection took place in March, it is still improbable that students after only six months of exposure to academic texts and concepts should have had any substantial effects on their metacognitive skills. On this background, it does not reduce the confusion, however, that the researchers themselves not only admit this, but even explicitly point out that the PIRLS study should be considered primarily as an indicator of reading competence at the end of the introductory reading program (Gabrielsen \& Strand 2017: 15).

Of course, there is the alternative interpretation that metacognitive thinking is supposed to be trained independently already at the elementary stage in school. But this is an option that the PIRLS researchers explicitly does not recommend (Berge et al. 2017: 168,ff.)

My main motive for addressing Vygotsky's hypothesis, then, is that influential contemporary researchers, at the same time as they seem to share Vygotsky's assumption that strategies are regulated by the reader's underlying metacognitive abilities, seem unfamiliar with his assumption that metacognition and strategic thinking will not develop until the students reach the middle stage. This may, at least in the case of the PIRLS study, have affected the conception on metacognition and strategies in a way that fosters confusion among readers. In this article, I therefore aim to reduce the foundation for confusion, by discussing Vygotsky's hypothesis and its educational implications. And as Vygotsky's conception of reading instruction and the development of reading skills are closely related to instruction in general as well as to cognitive development, I will take as my point of 
departure, Vygotsky's own view on how cognitive functioning develops, including his own comparison with Piaget's perspective as far as the relationship between instruction and cognitive development is concerned.

Table 1. The development of cognition according to Piaget and Vygotsky

\begin{tabular}{|l|l|l|l|l|}
\hline $\begin{array}{c}\text { Structures of } \\
\text { generalization } \\
\text { Piaget }\end{array}$ & $\begin{array}{c}\text { Thought } \\
\text { operations } \\
\text { Piaget }\end{array}$ & $\begin{array}{c}\text { Structures of } \\
\text { generalization } \\
\text { Vygotsky }\end{array}$ & $\begin{array}{c}\text { Thought } \\
\text { operations } \\
\text { Vygotsky }\end{array}$ & $\begin{array}{c}\text { Specific types } \\
\text { of relationship } \\
\text { of generality } \\
\text { between general } \\
\text { and specific } \\
\text { concepts }\end{array}$ \\
\hline $\begin{array}{l}\text { The sensory- } \\
\text { motor stage }\end{array}$ & $\begin{array}{l}\text { Sensory-motor } \\
\text { thinking }\end{array}$ & Syncretic & $\begin{array}{l}\text { Syncretic } \\
\text { thinking }\end{array}$ & Extrasystemic \\
\hline $\begin{array}{l}\text { Pre-operational } \\
\text { stage }\end{array}$ & $\begin{array}{l}\text { Pre-operational } \\
\text { thinking }\end{array}$ & Complexes & $\begin{array}{l}\text { Thinking in } \\
\text { complexes }\end{array}$ & Extrasystemic \\
\hline $\begin{array}{l}\text { Concrete } \\
\text { operational stage }\end{array}$ & $\begin{array}{l}\text { Concrete } \\
\text { operational } \\
\text { thinking }\end{array}$ & Preconcepts & $\begin{array}{l}\text { Thinking in } \\
\text { preconcepts }\end{array}$ & Extrasystemic \\
\hline $\begin{array}{l}\text { Formal } \\
\text { operational stage }\end{array}$ & $\begin{array}{l}\text { Formal } \\
\text { operational } \\
\text { thinking }\end{array}$ & Concepts & $\begin{array}{l}\text { Thinking in } \\
\text { (scientific, } \\
\text { academic) } \\
\text { concepts }\end{array}$ & Systemic \\
\hline
\end{tabular}

As summarized in table 1, Vygotsky assumes that each structure of generalization (i.e. syncretic, complexes, preconcepts and concepts) corresponds with characteristic thought operations associated with a given level of development of word meaning, and a specific system of generality and specific types of relationship of generality between general and specific concepts (Vygotsky 1987: 225). It is interesting to note that Vygotsky, as far as the general picture is concerned, does not point to any major disagreements with Piaget. Thus, he shares Piaget's opinion that all spontaneous concepts (thinking in complexes / pre-operational thinking as well as thinking in preconcepts / concrete operational thinking) are non-systemic. Further, he supports Piaget's observation that the child's thought is insufficiently connected or deductive and that the need to avoid contradiction is generally absent in his thinking. Vygotsky shares the view that the child's thought is more similar to a collection of lines flowing from the action or day-dream than it is to the adult's thought, which is systematic and characterized by conscious awareness (Vygotsky 1987: 234).

Finally, Vygotsky also supports Piaget's opinion that the absence of a system is an essential feature of the spontaneous concept (Vygotsky 1987: 234, 236). What Piaget does not understand, however, Vygotsky remarks, is that the nonsystemic nature of these concepts is not simply one of many features of the child's thought. It is in fact the root that gives rise to all the characteristics of the child's thinking that Piaget identifies (Vygotsky 1987: 234). 


\section{The general argument}

As an introduction to the general argument which I will develop in the following, Vygotsky illustrates the difference between thinking with preconcepts and thinking by means of non-spontaneous concepts - by clarifying the implications for thinking of the concept flower in relation to concepts like rose, rose, violet, or lily. He states:

The relationship of the word flower to the object is completely different for the child who does not yet know the words rose, violet, or lily than it is for the child who does (Vygotsky 1987: 234, italics added).

This relationship is characterized by the fact that it [flower] is mediated through other concepts [rose/violet]. Consequently, in its relationship to the object, the non-spontaneous (scientific) concept [flower] includes a relationship to another concept, that is, it includes the most basic elements of a concept system (Vygotsky 1987: 192, italics added.), [meaning that] "... a different relationship between the concept and the object develops. Supra-empirical connections between concepts become possible" (Vygotsky 1987: 234, italics added).

The reason why the flower concept implicates the most basic elements of a concept system, Vygotsky explains, is therefore that the relationship of:

[...] subordinate concepts to the given concept must be defined by the system created by the higher concept. If this were not so, the higher concept would not be higher than the given concept. This higher concept [then] presupposes both the hierarchical system and concepts subordinate and systematically related to the given concept. Thus, the generalization of the concept leads to its localization within a definite system of generality. These relations are the foundation and the most natural and important connections among concepts. Thus, at one and the same time, generalization [also] implies the conscious awareness and the systematization of concepts (Vygotsky 1987: 192, italics added).

\section{Implications}

One implication of Vygotsky's argument thus far, is that categorization most fundamentally, involves generalization, i.e. the establishment of relations between elements based on similarity. In spite of the extrasystemic nature of the child's spontaneous thinking, it reflects the capacity for generalization. The limitation, however, is that"... the only possible connections between concepts [which exist outside a system], are those that exist between the objects themselves, that is, empirical connections (Vygotsky 1987: 234), which often may reflect superfluous similarities.

Thus, in order for generalization to be systematic, it also requires that the individual is able to identify the abstract traits of the object, which is essential for the inclusion in a certain category. What is needed for thinking in concepts (formal operational thought), then, is the ability to categorize elements according to common components in reference 
(Rommetveit 1972), an ability that does not appears in the child's cognition before the age of eleven, and which is not stabilized before the age of thirteen (cf. Fox \& Risconscente 2008). Because abstraction not only involves the capacity to distinguish certain important characteristics of an object, but also to keep these characteristics in mind without having to attach it to specific objects in the room, they need to be formulated. This is why the transition to operations mediated by signs appear late in the child's thinking (Vygotsky 1987: 133).

It follows from this argument that individuals who do not master the art of abstraction, will also have problems with precise generalization, which is precisely the weakness that is reflected in the child's spontaneous concepts, and which can be traced back to their extrasystemic nature. When complexes are characterized by overgeneralizations, then, it is because the child cannot generalize in a systematic way, because he does not yet master the ability of abstraction.

\section{The system and its fundamental importance}

According to Vygotsky, the identification of the essential traits needed is possible only within a definite system of generality, where, as already indicated: “. . a different relationship between the concept and the object develops" (Vygotsky 1987: 234). The rose example shows that the most basic elements of a concept system is that the relationship of subordinate concepts to a given concept must be defined by the system created by the higher concept, so that "Supra-empirical connections between concepts become possible" (Vygotsky 1987: 234). Accordingly, it is only within a system that the relationships between concepts begin to emerge. And when these relationships are formulated verbally, they mediate the concept's relationship to the object through its relationship to other concepts (Vygotsky 1987).

The inadequate nature of the child's deductions, which Piaget also points out, therefore stems from an underdevelopment of the connections among concepts along the longitudinal axis representing the relationships of generality (Vygotsky 1987: 235), which make the child insensitive to the contradictions present in his own judgment. Contradiction can only be sensed, when two contradictory judgments are viewed as particular cases of a single, more general concept. Where concepts are not included in some system, however, this type of relationship among concepts is absent (Vygotsky 1987: 235).

In fact, this type of relationship according to Vygotsky, is impossible without the concepts' inclusion in some system, i.e. without systematic abstraction, because what the mediation process will make explicit, as it takes place in a systematic way within a hierarchical system of concepts, is precisely the criteria needed to counteract the overgeneralization (or under-generalization) of complexive and pre-operational thinking. Moreover, in order to be able to control and to regulate generalization (and thinking), this ability is necessary. Thus, it is thinking within a system, through the identification and definition of systematic concept relations, which secures that the processes of generalization, is bal- 
anced by the process of abstraction. At this point, we are getting close to the emergence of metacognitive control and regulation.

\section{Instruction}

These processes cannot just occur spontaneously, Vygotsky claims. According to their systematic nature, they need to be established in instruction:

While spontaneous concepts (rose - violet - lily) create the potential for the emergence of nonspontaneous (scientific) concepts in the process of instruction, instruction is the source of the development of this kind of new concept (Vygotsky 1987: 194, italics added).

Instruction begins with the work on the concepts verbal definition, with the mental operations [especially abstraction] that presuppose the nonspontaneous application of this concept (Vygotsky 1987: 217). Arising from above, from the womb of other concepts within a system, they are born through relationships of generality among concepts that are established in the process of instruction. By their very nature, scientific concepts in themselves include something of these relationships, some aspect of a system of concepts (Vygotsky 1987: 236), i.e. implicit criteria for abstraction, and these are clarified - in instruction - in relation to the system. This is why the scientific concept is of such extraordinary importance for the history of the child's mental development.

\section{Verbalization in instruction}

Thus, and even more importantly, it is when the criteria of abstraction needed to balance generalization are articulated in instruction they are also made available for conscious attention and conscious awareness. In this way, children become consciously aware of the concept and its relations to other concepts and the object. Thus, when students in instruction are working with concepts within a system, they are also gradually enabled to monitor or supervise their own thinking, in a way that enable them to conduct a continuous control of their own comprehension and effort (Vygotsky 1987: 194), which is exactly what metacognitive skills is all about.

\section{Conclusion}

It is on this background Vygotsky formulates the conclusion that it is only within a system that the concept can acquire:

“...conscious awareness and a voluntary nature. Conscious awareness and the presence of a system are synonyms when we are speaking of concepts, just as spontaneity, lack conscious awareness, and the absence of a system are three different words for designating the nature of the child's concept (Vygotsky 1987: 191-192, italics added). 
From this argument, it follows that the kind of thinking, which allows children to sense contraction in their own judgment, must be systematic in the sense that generalization is balanced by abstraction. When this ability, which implies the ability to think about one's own thinking, and which arises in the child's thinking as part of the development of their scientific concepts, their mental development is also raised to a higher stage (Vygotsky 1987: 236). The criteria of metacognition are not fulfilled, however, until the articulation of criteria for abstraction (and generalization) takes place, so that children gradually become consciously aware of the concept and its relations. It is not until this stage they are being enabled to monitor or supervise their own thinking, so that they continuously can control their own comprehension and effort.

As this also happens when children in instruction are working with concepts within a system, children's ability to control and regulate their own mental processes in a systematic way, are not only metacognitively related skills. They are based on the same skills that constitute metacognition, the ability to avoid contradiction in one's own judgment, mediated by the ability to balance generalization and abstraction.

In Vygotsky's view, then, the system (of concepts) is the cardinal point around which the whole history of concept development in the school age revolves, accordingly also the reason why conscious awareness - metacognition - as well strategic thinking, enters through the gate opened up by scientific concept (Vygotsky 1987: 191). Accordingly, the capability to monitor or supervise, control and regulate one's own thinking cannot be established before children in school start working with academic texts and concepts, i.e. at the middle stage. In addition, neither metacognition nor strategic (systematic) thinking can be established outside of the world of academic texts and instruction, as independent skills.

Following Vygotsky's hypothesis, then, metacognitive skills are not available for students at the introductory level, as the PIRLS report implies. Further, they are hardly available for students at 4th grade level in the PIRLS-study either. This is especially the case because Vygotsky claims that the effect of working with scientific concepts only gradually results in a more complete restructuring of the spontaneous concepts (Vygotsky 1987: 191). This statement is supported by Rommetveits finding that the ability to categorize elements according to common components in reference is not stabilized until the child is thirteen years old, although it appears two years earlier. It is also supported by Piaget's position that concrete operational thinking by nature is extrasystemic.

What I have managed to show in this article then is that Vygotsky's hypothesis that metacognitive abilities "... enter through the gate opened up by scientific concept" (Vygotsky 1987: 191) has the potential to clarify the confusion as to what metacognition is, and how it is developed, awakened by the PIRLS report. Therefore, researchers should not just ignore it when they plan and conduct studies. Before omitting it, they should articulate explicitly why it is not relevant for research on metacognition and strategies in reading. 


\section{References}

Afflerback P., Pearson P.D., \& Paris S.G. (2008), Clarifying differences between reading skills and reading strategies. "The Reading Teacher", 6.

Berge I.M., Helgevold L., \& Schulz-Heidorf K. (2017), Hva laererne rapporterer om egen undervisning $i$ strategier. In: E. Gabrielsen (Ed.), Klar framgang! Leseferdighet på 4. og 5. trinn i et femtenårsperspektiv. Oslo, Universitetsforlaget.

Flavell J.H., Miller S.A., \& Miller P.H. (2002 [1987]), Cognitive development (4th ed.). Upper Saddle River, N.J., Prentice Hall.

Fox E. \& Risconscente M. (2008), Metacognition and Self-Regulation in James, Piaget, and Vygotsky. "Educational Psychology Review", 20. doi:DOI 10.1007/s10648-008-9079-2.

Gabrielsen E. \& Strand O. (2017), Rammer og metoder for PIRLS 2016. In: E. Gabrielsen (Ed.), Klar framgang! Leseferdighet på 4. og 5. trinn i et femtenårsperspektiv. Oslo, Universitetsforlaget.

Haugen C.R. (2014), Hva er egentlig grunnleggende ferdigheter? In: C.R. Haugen \& H.T.A. (Eds.), Pedagogikk, politikk og etikk. Demokratiske utfordringer og muligheter i norsk skole. Oslo, Universitetsforlaget.

Klette K. (2007), Bruk av arbeidsplaner i skolen - et hovedverktøy for å realisere tilpasset opplaering? "Norsk pedagogisk tidsskrift", 91(4).

Kulbrandstad L.I. (2003), Lesing i utvikling: teoretiske og didaktiske perspektiver. Bergen, Fagbokforl.

Kulbrandstad L.I. (2018), Lesing i utvikling: teoretiske og didaktiske perspektiver (2. utg. ed.). Bergen, Oslo, Fagbokforl. Landslaget for norskundervisning.

Popkewitz T. (1998), Struggling for the Soul. The Politics of Schooling and the Construction of the Teacher. New York, Teachers College Press.

Pressley M. (2000), What should comprehension instruction be instruction of? In: M. Kamil, P. Mosenthal, P.D. Dole, \& R. Barr (Eds.), Handbook and reading research (Vol. III). Mahwah, Erlbaum Associates Publishers.

Roe A. (2014), Lesedidaktikk: etter den første leseopplceringen (3. utg. ed.). Oslo, Universitetsforl.

Rommetveit R. (1972), Språk, tanke og kommunikasjon: ei innføring i språkpsykologi og psykolingvistikk. Oslo, Universitetsforl.

Rydland V. (2007), Minoritetsspråklige elevers skoleprestasjoner: Hva sier empirisk forskning? Acta Didactica, Upaginert.

Vygotsky L.S. (1987), Thinking and Speech. In: R.W. Rieber \& A.S. Carton (Eds.), The Collected Works of L.S. Vygotsky (Vol. 1: Problems of general psychology). New York, Plenum Press. 